\title{
A Comparative Study on Child Abuse and the Absence of Legal Protections for Male Child Sex Abuse Victims in Major South East Asian countries
}

\author{
Ali Raza Ansari ${ }^{1, *}$, Alexandra Jane Davis ${ }^{2}$ and Nishan-E-Hyder Soomro ${ }^{3}$ \\ 1 Guanghua Law School, Zhejiang University, Hangzhou, China \\ 2 Guanghua Law School, Zhejiang University, Hangzhou, China \\ 3 School of Law and Economic, Zhengzhou University, Zhengzhou, China \\ *Corresponding author. E-mail: ara_7@live.com \\ https://doi.org/10.12982/CMUJASR.2020.008
}

\begin{abstract}
The focal point of this paper is in highlighting the grim picture in dominant Asian countries China, India, and Pakistan where no practical application of the law is found to protect against the sexual abuse of children, particularly underage boys. An analysis regarding the conditions of sexual abuse in the aforementioned countries is carried out using the scarce reports issued by national governments, which will be supplemented with information from prominent NGOs and media reports. Thereafter, certain gaps in the justice system and law enforcement are identified. Simultaneously, the Western perspective is studied to ascertain how this issue is being addressed in Western societies and to what extent this heinous crime has impacted the lives of individuals. Finally, there is deliberation as to what the East could learn from Western practices for curbing the often-hidden menace of male child sex abuse.
\end{abstract}

Keywords: Child abuse, Child sex abuse, Comparative study, Eastern practice, Gaps in justice system, Law enforcement, Male child abuse, Media reports

\section{INTRODUCTION}

The phenomenon of child abuse is not a new concept in the World; the history of child abuse could be traced back to ancient times during the Roman Era where the male head of the family had the sole authority to decide whether a child is allowed to live, die or to be sold as a slave (Public Health Foundation of Georgia, n.d.). Likewise, Babylonian law reflected a similar situation where if a son strikes his father, he was punished with hand amputation (Duiker and Speilvogel, 2017). The Spartans used to throw infants from the cliffs if the child failed at what they called the "grasping reflex technique," which was used to ascertain neurological defects in children (Hussain, 1982). A poor result in this test meant that the child was deemed unfit for survival. Moreover, recent archeological research from the Romano- 
Christian Era has revealed a case of child abuse from 2,000 years ago where a toddler aged between 2 to 3 fell victim to repeated force and trauma (Castro, 2013).

Evidence of ancient child abuse is not limited to mere physical violence (Child abuse - A history, n.d.), but rather extends into sexual violation. For example, in ancient Greece, pederasty was commonplace and young boys of elite families were often kidnapped and used as sex objects by other aristocratic males (Chrystal, 2018). Poor boys were flouted by society in boy brothels - these flourished in every city - , which provided contractual "rent-a-boy" services (Weisberg, 1984, pg. 1-2, n.1). Young boys in ancient Rome fared no better. Although aristocratic boys were often spared sexual abuse by the men around them, aristocrats often kept slave boys to use for their own sexual pleasure (Weisberg, 1984).

Child abuse has also been a common practice in modern western society as children were considered personal property of their fathers until fairly recently (Mason, 1994). However, with the passage of time things started to change. In 1874, a 10-year-old girl, "Mary Ellen McCormack," raised her voice against the constant abuse she faced, and she compelled authorities to take strict notice of the existence of child abuse in society (Markel, 2009). The same incident led to the establishment of the "New York Society for the Prevention of Cruelty to Children," which was the world's first agency for child protection (Watkins, 1990). Scientific and psychological progress led to the establishment of a specific term designated for abused children called "battered child syndrome," which was coined by a famous pediatrician Doctor Henry Kemp, in 1962 (McCoid, 1965). Finally, the world community joined their hands for a greater cause and, in 1989, the first ever unified treaty for child protection known as the "United Nations Convention on the Rights of the Child" (UNCRC) was born and supported by the United Nations Children's Fund (UNICEF) (UNICEF, n.d.).

\section{Child Abuse and Eastern Society}

Child abuse in Asian society has a long history, the traces of which can be observed from the old Chinese tradition of foot binding (Barns, 2017) - a process that causes severe misery for the child as it inflicts extreme pain. This was practiced on girls of around seven years old (Mills, 2015) with some being as young as four or five (Schiavenza, 2013). The practice was carried out so that the girls could attain a look that men of the era found physically attractive and desirable. In the past, very limited research was conducted in the Asia Pacific Region concerning the matter of child abuse (Dunne, et al., 2015). However, bodies like UNICEF had gradually begun to call attention to the matter. From 2000 to 2013, UNICEF conducted research on sexual abuse in the East Asia-Pacific region, the results of which reflected an extremely critical situation regarding sexual abuse towards boys. The study revealed that about 3 to $16.5 \%$ of boys were being sexually abused in the region during the period of data collection (UNICEF EAPRO, 2014). UNICEF published another report on child abuse covering the East Asia-Pacific region, which showed horrifying trends from the collected data of 364 studies over a period of 10 years. The findings demonstrated that 1 out of every 4 children had suffered some form of extreme physical abuse in the region (McCoy, 2014). In China, the results of a total of 68 studies showed that about $8.7 \%$ of children in the country had been abused sexually, (Fang, et al., 2015), and this number could be even greater than what the studies 
revealed ( $\mathrm{Fu}$, et al. 2018). The phenomenon and prevalence of child abuse in China stems from the Chinese notion that if one is beating a child, it means that he is caring for that child; likewise, scolding a child equates with loving a child - especially when dealing with sons (Qiao and Chen, 2005). It is a basic norm in Chinese society that whatever happens in the home remains in the family, effectively silencing children and creating an environment for abuse to proliferate (Yong, 2015). Similarly, countries like Afghanistan, which places great value on keeping outside influences away from the practices at home, remain in the news for violations to children (Humanium, n.d.). A 2018 study, in which 145 kids and 104 parents in Afghanistan were surveyed, revealed that around $71 \%$ of the responding children faced physical abuse (O'Leary, et al., 2018). Furthermore, there is a specific trend in Afghanistan whereby rich men keep young boys for the fulfillment of their sexual desires; many people consider the act as a sign of higher status, and it is thus not viewed as a matter of child protection or abuse. (Jabeen, 2013)

\section{SEXUAL ABUSE CASES INVOLVING MALES, PARTICULARLY BOYS, IN CHINA}

It is true that sexual abuse involving males is, comparatively speaking, a new topic of interest in China, and thus does not have an extensive history (Dunne, et al., 2008). However, recent studies suggest that male sexual abuse is more prevalent than previously thought. In a study focused on rural areas of China and published in 2011, a total number of 863 children ranging from ages 8 to 18 were surveyed, and out of which 123 kids reported sexual abuse before they reached the age of 16 (Lin, et al., 2011). Notably, more boys reported to have experienced sexual abuse than girls-around $21.5 \%$ in comparison to $14.2 \%$-(Lin, et al., 2011). A similar survey conducted in 2004 that extended to four different provinces of China anonymously surveyed 3261 students; here, a staggering $70.5 \%$ of students reported some kind of sexual abuse with $10.5 \%$ of those responders indicating that they were male (Chen, et al. 2004). Likewise, the 2005 Chinese Youth Risk Behavior Survey (CYRBS) - the first ever nationwide survey to address sexual coercion amongst adolescents in China-found that out of 5,215 respondents, 1,706 indicated that they had been victims of sexual coercion, and 29.6\% were male (Song, et al., 2014). Another study conducted in Hong Kong also revealed that boys were three times more likely to be sexually abused by their friends in comparison to girls - who are more often abused by strangers (Tang, 2002). In 2017, China's first ever reported male-on-male rape conviction resulted in a punishment of just one year imprisonment along with a year-long probation, despite the fact that the culprit was HIV positive at the time of committing the crime (Feng, 2018).

\section{Gaps in Male Sex Abuse Protection in China}

In 2017, a report published by UNICEF put forward the notion that child abuse cases are not being treated as a priority in the nation, and that despite taking several measures, legal and educational staff are not qualified to deal with such affairs (UNICEF, 2017). Moreover, there is no available platform for child protection at the national government level, which impacts upon the mandatory reporting of child abuse (UNICEF, 2017). Furthermore, the regulation of Child Online Protection, 
which was passed in 2019 (Zhang and Chen, 2019), lacks sufficient protection measures so as to make a real difference in tackling child abuse. According to the researcher Shang Xiaoyuan, around 12 percent-meaning 270 million-of Chinese children are abused in China, yet the total number of cases heard by Chinese Courts from 2015 to 2018 was 11,519 (As cited in Yan, 2019). Looking at the lack of available resources for the detection and prevention of child sexual abuse, Professor Tong Xiaojun from the China Youth University for Political Studies stated "[w] hat China has done in protecting children is far from enough" (Yan, 2019).

The most concerning aspect of China's child protection system is that despite making several amendments to criminal law (Criminal Law of the People's Republic of China [Criminal Code of China], 2015), the crime of rape is still restricted to only female penetration in current legislation. Although the penal code was amended in 2015 to protect men from "indecent assault," Article 236 of the Criminal Law specifies rape as an action committed against a female (Criminal Code of China, Art. 236; Zheng, 2017) ${ }^{1}$. This has led to instances of male rape going unreported or not being taken seriously by the courts or law enforcement. For example, in 2014, a man reported that he had been raped, but the police did nothing due to the ambiguity in the law and the accused was subsequently released after receiving a warning $(\mathrm{Wu}$, 2014). Another problem that arises is police indifference or hostility towards child abuse victims, even when the victim is a girl. A recent case involving a prominent businessman accused of raping a 14-year old known as "Xingxing" attracted major headlines and marked a period of public contemplation about both the vulnerability of children in China and the barriers that victims often face to registering the case (Hernandez, 2020). Specifically, the case highlighted the fact that, in such scenarios, authorities often side with dominant or rich figures in society to the detriment of poor or minor accusers - particularly since China's current age of consent is 14. Such were the circumstances in XingXing's case that the complaint was dismissed several times by the police (Hernandez, 2020). The Chinese lawyer Wang Yongmei suggested that China needs a child protection forum/agency to deal with these kinds of conditions, and a specialized police force to support rape victims (Barczyk, 2020).

\section{PREVAILING MALE SEXUAL ABUSE IN INDIAN SOCIETY}

The World Health Organization states that globally 1 out of every 13 adult males reported that they were sexually abused as children (World Health Organization [WHO], 2020). This number is even higher in India where there is a culture of systematic abuse of young males. One of the largest minority groups in India are male homosexuals (Mimiaga, et al., 2014). Studies show that a history of sexual abuse has been prevalent in India's homosexual community, and that this has contributed to the psychological distress which the men felt in adulthood (Mimiaga, et al., 2014, pg. 3, fig. 1). In a study done on the homosexual population in Chennai, $25 \%$ of the participants reported experiencing unwanted sexual contact in their

\footnotetext{
1 Distinguished lawyer Zheng Zhiyin explains that "while the 2015 amendments to the penal code have expanded the definition of indecent assault to include more victims, this has not been matched with corresponding amendments to Articles 236 and 240, which deal with rape and the trafficking of women".
} 
childhood (Mimiaga, et al., 2014, pg. 4). Most of the men reported being abused by a male figure close to them ${ }^{2}$ and stated that they believed this unwanted sexual abuse precipitated their current homosexual status (Mimiaga, et al., 2014). Two men even reported that their sexual trauma as children led them to become "addicted" to homosexual sex (Mimiaga, et al., 2014). In another study done by Johns Hopkins University, out of 11,788 men sampled who had sex with other men (MSM), 22.4\% reported that they had experienced childhood sexual abuse (Tomori, et al., 2016). Similarly, childhood sexual trauma had a significant impact on the men's future sexual experiences with other men, with many of the males turning to sex work shortly after suffering their abuse (Tomori, et al., 2016). Furthermore, the men who had been abused as children were twice as likely to engage in behaviors or experiences that carried the risk of HIV exposure (Tomori, et al., 2016). However, this abuse is not just prevalent among India's homosexual minority, it also runs rampant in minority tribes such as the Baiga (Iravani, 2011). In this community, incestuous marriage is still practiced and children as young as 5 or 6 are often taken from their homes "to spend the rest of their childhood in sex dormitories, where they are initiated by older youth and men into intercourse with a succession of other children" (Iravani, 2011, pg. 150). In another study sampling "adolescent street boys" in Mumbai City, 31.9\% of respondents reported having been victims of sexual abuse (Gaidhane, et al., 2008).

Even in India's general population, studies have found that around $30 \%$ of Indian men remember being sexually molested as children; of those men, $81 \%$ had experienced the abuse before attaining puberty, and $42 \%$ had experienced molestation before the age of 7 (Iravani, 2011, pg. 150). More notably, a review looking at 51 studies conducted between 2006-2016 revealed that the sexual abuse ratio among boys in educational institutes was either the same or, potentially, much higher than girls; a range between $4 \%-57 \%$ of boys reported sexual abuse across the various studies, with 4-41\% of girls reporting abuse in the same studies (Choudhary, et al., 2018). Many reported that the abusers were known to them, or were family members (Choudhary, et al., 2018, pg. 15). However, the same study also found that adolescent boys were more likely to be sexually abused by strangers than adolescent girls (Choudhary, et al., 2018, pg. 15). Furthermore, the review found that male sexual abuse was more likely to become a vicious cycle as the young boys who had reported being abused during childhood had an "increased risk of becoming young sexual offenders" themselves (As cited in Choudhary, et al., 2018, pg. 15; Sahay, 2008). This can be illustrated by several rape cases seen in the news within the last year. For example, news of a 17 year old boy who was raped became viral when it was revealed that he was kidnapped by six men in a car while walking home and raped repeatedly by the different men while the car was still moving. (Times Now News, 2019) In another case, a 13-year-old boy was kidnapped and raped by four men in the province of Uttar Pradesh (News 18, 2019). In the same province, another 5-year-old boy was raped by a man who offered the boy sweets as a pretext for taking him to a secluded area and assaulting him (Choudhury, 2019).

\footnotetext{
2 Reported perpetrators included "adult male teachers, peers, coaches, employers, neighbors, uncles, and cousins." (Mimiaga, 2020)
} 


\section{Child Abuse Cases: A Cumbersome Process in India}

The amount of child abuse cases has jumped drastically in India over recent years; according to the National Crime Bureau of India, around 109 children were sexually abused on average each day in 2018 - a $22 \%$ increase from the previous year (Sengupta, 2020). More significant still, the same agency found 1 rape being reported every 15 minutes in India, reflecting a much darker picture (Anand, 2020). This has led India to attempt to protect children from sexual predators through the enactment of the Protection of Children against the Sexual Offence Act (POCSO) in 2012. Because of POCSO, a larger number of child abuse cases were actually reported, in contrast to previous times when such crimes often went unreported (National Crime Records Bureau [NCRB], 2015). For example, the findings of the Madras High Court conveyed that reports of crime against children in India had doubled between 2012 to 2014, and a 50.6\% increase was seen in rape cases (Crl.O.P.(Md)No. 11735 Of 2014 And ... vs State Represented, 2015). POCSO is far from perfect, however, and seemingly falls short of its goals of protecting children.

The deterrence of would-be sexual predators is virtually nonexistent under current conditions; just because a rape is reported or investigated under POCSO, it does not mean that a victim will get his/her day in court. Between 2012 and 2015 a total of 6,816 cases of sexual abuse were registered, and yet only 556 went to trial. More dismal still, only 166 of the abusers were convicted, while 389 ended in acquittal - a conviction rate of $2.4 \%^{3}$ (Crl.O.P.(Md)No. 11735 Of 2014 And ... vs State Represented, 2015). In a case decided recently by the Delhi High Court, the court decried the investigation process adopted for sexual abuse cases, finding the process lacked proper guidelines (Ashok Jaiswal vs State, 2019). Further gaps were identified including the allowance of broad discretion by the investigation officer during the course of investigation, and the absence of a child development or psychology expert on nearly all investigation teams (Ashok Jaiswal vs State, 2019). The Supreme Court of India took suo moto action last year (2019) in relation to the slow disposal process of child sex abuse cases in the capital city New Delhi (Express News Service, 2019). Here, the Chief Justice showed his frustration in observing that only 2 sexual abuse cases were disposed of in a 6-month period (Express News Service, 2019). Furthermore, despite the enactment of $\mathrm{PCSO}$, along with mandatory reporting, there is still a lack of conviction in tackling the issue of child sex abuse (CSA) among professionals, including doctors and police, which acts as a hindrance to the proper implementation of the law in India (Belur and Singh, 2015). For these very reasons, it is important that professionals such as child development experts become part of the investigation process if the spirit of POCSO is to be fully realized.

\section{CHILD RAPES IN THE PREVIOUS DECADE IN PAKISTAN}

The issue of child abuse is increasingly gaining more attention in Pakistan. Sahil, an NGO working on the subject of child abuse, noted that around 2,303 cases of child abuse were registered in 2011 alone (Khan, 2019). A report published by the

\footnotetext{
${ }^{3}$ The Chief Justice further found that "[e]very second, child in India is facing some form of abuse, irrespective of whether it is a girl or a boy."
} 
Human Rights Commission of Pakistan in 2016 revealed an increase of around 10\% in reported child abuse cases in a single year (Human Rights Commission, 2017). However, since then, the numbers paint an even graver picture. In 2017, data shows that around 3,445 children were reportedly abused in Pakistan, out of which 2,077 were girls and 1,368 were boys; of these cases, 29 boys and 36 girls were murdered after being raped (Business Recorder, 2018). In the same year, an 11 year old girl named Rubina was kidnapped from her job as a maid by a police official and transported to a house where she was forced to work as a domestic and sexual slave, during which time she was raped by the official numerous times (Khan, 2017). After being found by her parents a First Information Report (FIR) was launched against the official, and yet the officer faced no arrest nor suffered any repercussions since there is no specific law for the protection of domestic child workers (Khan, 2017). The year 2018 marked a devastating year for children in Pakistan as another innocent girl, Zainab Ansari, fell prey to the brutality of rape and murder (Sandhu, 2018). Despite possessing CCTV footage of her abductor and murderer, the police were reluctant to move quickly and were caught taking bribes shortly after the incident. Naturally, this caused a monumental public outcry. The case "raised numerous questions on the incompetence and maladministration" (Sandhu, 2018) of the Pakistani police force, and paved the way towards significant-albeit slowly reform after a two year delay via the Zainab Alert Response And Recovery Act of 2019 (Muzari, 2019) from the parliament (Khan, 2020). However, even with progress on the horizon, the data shows that more legislation is needed before this can be achieved. For example, during a six month period in 2019, 729 girls and 575 boys were reported as having been abused, with 12 boys and 4 girls murdered after being raped, and these were just cases covered by the media (Dawn, 2019). Meanwhile, in Punjab alone, 1,359 cases of child abuse were registered last year (Omer, 2020). The executive regional coordinator of Sahil suggested that proper awareness is mandatory as well as new legislation and, more importantly, its implementation along with the inclusion of rehabilitation centers is required to be drafted at the provincial level if there is any hope of protecting the most vulnerable children (Dawn, 2020).

\section{Sexual Abuse of Underaged Boys in Pakistan}

Recently, numerous rape incidents have surfaced in Pakistan involving male minors. For example, the rape and murder of 8-year-old Muhammad Faizan in September of 2019 marked the fourth case of abduction of young boys in just three months in the city of Chunian (Masood, 2019). It is believed that all the crimes were committed by one man who lured the boys away with the promise of being paid to collect firewood, before raping, killing and dumping their bodies (Masood, 2019). Likewise, in 2018, an 11-year old boy was kidnapped and raped by three men while he was walking home from a mosque in Texila city (Naseer, 2018). Last year, the Prime Minister of Pakistan ordered the removal of the top three police officials of Punjab province after three boys were raped and murdered and no arrests were made (Zulgernian, 2019).

Significant evidence from Pakistan shows that boys with lower-level professions, such as truck cleaning jobs are often forced into sex by their employers (Jan Willem De Lind Van Wijngaarden, \& Schunter, B.T.2014). Moreover, like in 
India and Ancient Greece, there is a cultural practice throughout Pakistan - and most notably in the KPK province-where affluent males keep young boys as their male concubines, treating them as objects to fulfill their sexual desires (Jan Willem De Lind Van Wijngaarden, \& Rani, B. 2011). Last year, a brutal case of child abuse emerged in the media where a young boy had been abused by his madrassa tutor in KPK and reportedly raped over 100 times (Mubashir, 2019). In the period from January to June of 2019, 575 cases of sexual abuse against boys were reported in the media, with 12 cases resulting in the death of the young boys after being raped by the perpetrators (Mubashir, 2019). The Punjab alone saw 1,359 cases of child sexual abuse registered in 2019 (Omer, 2020). Moreover, the data shows that of the 1,359 cases, sexual abuse against boys greatly outweighed that of girls (Omer, 2020). For example, in Lahore, 88 of the reports involved the abuse of boys compared to 17 in the case of girls; likewise, in Gujrat, there were 22 reports of child sexual abuse cases involving boys in comparison to just one case involving a girl (Omer, 2020). This included a 13-year old boy who was raped and filmed by an abuser who, after being caught, confessed to abusing 30 other children (Ahmed, 2019). The most concerning thing in Pakistan is the commission of sexual abuse in Madrassas where clerics have the opportunity and usually unsupervised access to young boys - as illustrated by a recent case where a cleric forcefully took a boy into the toilet and tried to rape him (Gannon, 2020). Thus, boys are often left vulnerable and subjected to sexual abuse in a way that young girls are not.

\section{Problems in the Delivery of Justice in Child Abuse Cases in Pakistan}

Access to the courts is a significant problem for juveniles trying to litigate a case in Pakistan. According to the Ministry of Social Welfare and Special Education, $70 \%$ of juvenile offenders cannot afford proper legal representation resulting in extended stays in pre-trial prisons, leaving them open to abuse 4 (PMSW, 2006). Furthermore, according to the same report, Pakistan has no national database or reporting agency that tracks child sexual abuse - leaving the public to garner all of their data from NGOs like Sahil and the media (PMSW, 2006, pg. 44). However, even these organizations face difficulties in acquiring real data because of cultural concepts like "family honor," which cause abuse to go largely unreported (MSW, 2006, pg. 44). Moreover, police corruption or negligence results in the reported cases rarely making it to the status of official investigation; according to data from 2014, out of a total of 383 sexual assaults reported in hospitals in the metropolitan city of Karachi, only $27.67 \%$ cases were formally registered by the police (A. Khan, 2015). The data was collected from 112 different police stations in the city where only 106 FIRs were registered (A. Khan, 2015). Normally, victims and their families opt to settle matters between themselves since: firstly, relief outside of court is often swifter and more attainable; and secondly, victims are intimidated by the attitude of police and prefer not to seek formal help, which is due (A. Khan, 2015) specifically to the dark history of sexual abuse of boys at the hands of police in Pakistan (Berit, et al., 2003). The 2019 report of the Human Rights Commission of Pakistan claims that children are under the severe threat of physical and sexual abuse from police, which

\footnotetext{
4 It should be noted that the same indicates the "minimum age of criminal responsibility is seven years which
} leads to children being treated and judged like adults." (PMSW, 2006, pg. 44) 
is clear evidence that child protection laws are not being implemented in the country (U.S. Dept. of State, 2019).

Another huge problem with Pakistan is the implementation of laws like the "Zainab Alert" since, due to the 18th amendment, the power to enforce laws does not solely remain with the federal government. This means that it is the prerogative of provincial governments whether they adopt any child protection laws, or alternatively pass similar/ new laws (Khan, 2020). Furthermore, the political influence of certain conservative groups often hinders justice, as seen in the case of boy of Manshera whose family was pressured by the JUI-F party to settle the reported abuse amongst themselves rather than knocking on the doors of authorities (Mubashir, 2020). Moreover, child abuse in Madrasas is a severe problem in Pakistan as the influence of Mullahs in society places huge barriers in the path of justice. In most cases, it is hard to get clerics convicted because families of victims are often urged by neighbors, other family members, and friends to forgive the abusers (Mubashir, 2020). The biggest problem with the Pakistani justice system is the extremely slow trial process for rape cases, as was seen in the high-profile case of Mukhtara Mai, which took 17 years to deliver an outcome (Gandhara, 2019).

\section{CHILD ABUSE IN WESTERN SOCIETY AND ITS IMPLICATION FOR VICTIMS}

There is no denying that child abuse is a concerning issue in the West (Finkelhor, 2019). According to the American Society for the Positive Care of Children (2020), reports of child abuse were lodged involving 7.8 million children in the United States in 2018. In West Virginia alone, 39,737 reports of abuse or neglect were filed and formal investigation was deemed necessary in nearly two-thirds of the reports (Child Welfare League of America, 2019). In Glasgow, Scotland, a 16-year old boy raped a 7-year old boy in a graveyard and threatened to kill him if the boy reported the crime ("Teenager Raped 7-year old Boy", 2019). A similar case emerged in the news in Houston, Texas, when a 13-year old boy, while walking back to his home, was kidnapped by a stranger who raped him and left him undressed in the cemetery ("Boy, 13, raped”, 2019). Today's children are not just vulnerable to predators lurking in their neighborhoods, they also face the threat of online abuse. According to a study conducted in Sweden, 30\% of respondents (aged between 14 and 15 years old) reported experiencing unwanted advances of a sexual nature over the internet by an unknown adult (Jonsson, et al., 2019). In a different study sampling high school seniors in Sweden, when questioned about experiencing sexual abuse by a person they met online, 330 students admitted to having a sexual encounter with someone they met over the internet and $9.7 \%$ of those students felt that they had been coerced into the encounter (Jonsson, et al., 2019). The internet can also be a way of exploiting and proliferating child sexual abuse through the use and sharing of pornographic images of children. In its 2019 annual report, the Internet Watch Foundation urged European countries to take a serious look into the protection of child victims as $89 \%$ of "known URLs containing child sexual abuse material were hosted in Europe" - 71\% of which were hosted in the Netherlands (Internet Watch Foundation, 2020). 
The lives of childhood sexual abuse survivors are impacted in many ways. Survivors may experience problems like Post-Traumatic Stress Disorder (PTSD) as one of the complications they face throughout their life (Wolfe, 2007). Other psychological reactions seen in childhood abuse victims include fear, nervousness, guilt, sadness, and self-confinement (Putnam, 2003). Experiencing child abuse increases the chances of engaging in risky sexual behavior like "transactional sex," which includes receiving money or gifts in return for providing sex. Importantly, this also increases the probability of the transmission of sexual diseases (Thompson, et al., 2017), including HIV and Hepatitis. (Widom et al., 2012)

\section{Child Protection in the West vs. the East}

It appears that child abuse is dealt with more seriously in the West as there are many forums and protections put in place to report abuse and receive emotional/legal support in Western countries. For example, according to the Child Abuse Hotline, a report of child abuse is made every 10 seconds in the USA (ChildHelp, 2014), and similarly, the United Kingdom's Childline delivered 19,847 counselling sessions to children in the UK where abuse was the primary concern, and around 1 in 20 of the sessions resulted in a referral to external agencies (Elkin, 2020). However, the process of reporting or registering complaints of child abuse in China, India, and Pakistan results in most cases going unreported.

Offenders are also punished more severely in the West and seeking retribution or legal repercussions is often out of the hands of the guardian or biological parent, thus protecting families from the pressure of settling out of court or keeping it between themselves. To illustrate the severity of punishment, in Canada David and Louise Turpin were sentenced to life in prison in 2019 for the torture and starvation of 12 of their children ("Turpin Trial Couple Jailed", 2019). Likewise, there is much stricter monitoring of online child abuse activities. In April 2020, Australian officials apprehended a man who had used "an encrypted online messaging forum to share abhorrent videos of children being sexually abused" ("Mid West Man Charged", 2020). Moreover, the trend of lengthening statute of limitations periods for child rape cases had led to a number of alleged rapists being arrested for charges relating to the past, lending a voice to victims who were too young to self-report the crime when it was committed. For instance, thirty-three men from Calderdale, Bradford and Kirklees in the UK were arrested and charged in February 2019 in connection with historic child abuse in connection with historical child abuse ("Thirty-Three Men Arrested," 2019) following the arrest of fifty-five men in January of the same year for similar offences. Similarly, in countries like the USA national/federal agencies such as the Department of Bureau of Justice Statistics or the Administration of Children and Families, annual reports of sexual abuse cases and reports of abuse towards youths in juvenile facilities are published (Smith \& Windico-Stroop, 2019). This is an important contribution to the checks and balances on the police or facilities that house children away from the care of their own families. Furthermore, many Western countries have separate court procedures for dealing with child abuse and neglect proceedings, which helps protect victim identities and can expedite the investigation/trial process. For example, the West Virginia Judiciary's (2020) Rules of Procedure for Child Abuse and Neglect Proceedings stated that the purpose of such rules is to "provide fair, timely and efficient disposition of cases involving 
suspected child abuse or neglect," and "reduce unnecessary delays in court proceedings through strengthened court case management." Conversely, China, India, and Pakistan often do not conduct annual reports and have few, if any, agencies devoted to the protection of children from abuse or sexual violation. ${ }^{5}$ Moreover, Western nations often have private organizations or NGOs dedicated to the protection of children, the response to sexual abuse, and the health and wellness of child survivors - many of whom receive government funding or grants. ${ }^{6}$ Unfortunately, the same cannot be said in the East. Even with NGOs like Girls' Protection in China, Sahil in Pakistan, and HEAL in India, there are still many victims left without support to report the crime or opportunity/access to emotional therapy afterwards 7 (Yuan, 2019; HEAL, 2017).

\section{CONCLUSION}

As China, India, and Pakistan are all signatories of the United Nations Convention on the Rights of the Child, it is necessary that they should take measures so that children are protected in accordance with Article 19 and 34 of the UNCRC. Since the combined population of the three nations equates to around 2.92 billion of the total world population, it is imperative that better protections are put in place. Despite the sheer number of children who are left vulnerable by their current legal systems, the approach of these major Eastern countries in dealing with child sexual abuse is borderline neglectful, specifically towards males. There is no denying that sexual abuse towards boys is an issue all over the World; however, victims tend to be taken more seriously and are given better access to legal retribution than in the East. In Eastern society, the concept of male rape is unfortunately denied due to the cultural ideology of males not needing protection. Simultaneously, there are institutional gaps in dealing with abuse cases, from the absence of serious police investigation to the limited number of cases that go to court. Furthermore, the lack of medical experts and victim advocates involved in reports of child rape leads to victims being pushed to the background, and leads to many survivors' general distrust of the police and the legal system. Moreover, none of these countries have an agency, body, organization, or particular law that monitors the sexual abuse of children on a gender equal basis. It is therefore required that proper reforms based upon the approach towards victims in the West should be implemented in both the investigation and follow-up of cases. Without such reforms, Asia's children will remain vulnerable and voiceless in the continuous cycle of sexual abuse.

\footnotetext{
${ }^{5}$ For example, Pakistan has no federal statistics available. (PMSW, 2006, pg. 44). It appears India last did a national study in 2007. The study is available at https://resourcecentre.savethechildren.net/node/4978/pdf/4978.pdf.

${ }^{6}$ It was recently revealed in an article from The Guardian that that over $75 \%$ of funding for the NGO Save the Children UK comes from governments. (Doane, 2018)

7 For instance, Sun Xuemei, head of the NGO Girls' Protection in China, reported to the media that "[v]ery few cases make it to court due to the stigma attached to it" (Yuan, 2019) while HEAL, an NGO in India, found in their study that " $83.3 \%$ of survivors participating in the study never disclosed information about the abuse to anybody" and that many practitioners in the study felt they were ill-equipped or untrained in providing medical services for child sex abuse victims.
} 


\section{REFERENCES}

Ahmed, A. (2019, November 12). Man arrested in Pakistan for raping and filming a minor boy confesses to raping 30 children. Gulf News. Retrieved 2020, from https:/ / gulfnews.com/world/asia/pakistan/man-arrested-in-pakistan-forraping-and-filming-a-minor-boy-confesses-to-raping-30-children-1.67772134

American Society for the Positive Care of Children. (2020, June 13). Child Abuse Statistics. Retrieved July 04, 2020, from https:/ / americanspcc.org/child-abusestatistics/

Anand, A. (2020, January 11). NCRB Data 2018: 1 Rape Reported Every 15 Minutes in India. India Today. Retrieved 2020, from https:/ / www.indiatoday.in/india/ story/ncrb-2018-woman-reports-rape-every-15-minutes-in-india-1635924-202001-11

Ashok Jaiswal vs State, https://indiankanoon.org/doc/93638560/ (Delhi High Court December 10, 2019) (Indian Kanoon, Dist. file).

Barczyk, H. (2020, April 23). The push to raise China's age of consent from 14. The Economist. Retrieved 2020, from https:/ / www.economist.com/china/2020/04/ 23/the-push-to-raise-chinas-age-of-consent-from-14

Barns, S. (2017, December 24). Horrific photographs show the centuries old Chinese practise of foot binding. The Sun. Retrieved 2020, from https://www.thesun.co. uk/fabulous/3574437/horrific-photographs-show-the-centuries-old-chinesepractise-of-foot-binding-that-breaks-bones-and-agonisingly-mutilates-the-toeslotus-shape/

Belur, J. and Singh, B.B. (2015). Child sexual abuse and the law in India: A commentary. Crime Science, 4(1). doi:10.1186/s40163-015-0037-2

Berti, S., Jacomy, S., and Vite, S. (2003, May). Rights of the Child in Pakistan [PDF]. Geneva: World Organisation Against Torture.

Boy, 13, raped and left naked in park, family says. Police haven't identified a suspect. (2019, November 15). CNN. Retrieved 2020, from https:/ / www.kltv.com/2019/11/15/boy-raped-left-naked-park-family-sayspolice-havent-identified-suspect/

Business Recorder. (2018, April 19). Child abuse cases on the rise: Report. Business Recorder. Retrieved 2020, from https://fp.brecorder.com/2018/04/ 20180419362788/

Castro, J. (2013, May 28). Earliest Case of Child Abuse Discovered in Egyptian Cemetery. Retrieved May 04, 2020, from https://www.livescience.com/34738egypt-cemetery-reveals-child-abuse.html

Chen, J., Dunne, M.P., and Han, P. (2004). Child sexual abuse in China: A study of adolescents in four provinces. Child Abuse \& Neglect, 28(11), 1171-1186. doi: 10.1016/j.chiabu.2004.07.003

ChildHelp. (2014, October 23). Child Abuse Statistics. Retrieved July 04, 2020, from https:/ / www.childhelp.org/child-abuse-statistics /

China, The Supreme People's Court of the People's Republic of China. (2015). Criminal Law of The Peoples Republic of China. Retrieved 2020, from http://english.court.gov.cn/2015-12/01/content_22595464_22.htm 
Choudhry, V., Dayal, R., Pillai, D., Kalokhe, A.S., Beier, K., and Patel, V. (2018). Child sexual abuse in India: A systematic review. Plos One, 13(10). doi: 10.1371/journal.pone.0205086

Choudhury, S. (2019, November 13). 5-Year-Old Boy Sodomised in Uttar Pradesh. India Today. Retrieved 2020, from https://www.indiatoday.in/crime/story/5year-old-boy-sodomised-by-man-in-uttar-pradesh-1618367-2019-11-13

Chrystal, P. (2018, January 18). A brief history of sex and sexuality in Ancient Greece. Retrieved June 15, 2020, from https://www.historyextra.com/period/ancientgreece/a-brief-history-of-sex-and-sexuality-in-ancient-greece/

Crl.O.P.(Md)No. 11735 Of 2014 And ... vs State Represented, https://indiankanoon.org/doc/154136594/ (Madras High Court October 16, 2015) (Indian Kanoon, Dist. file).

CWLA. (2019, April). West Virginia's Children [PDF]. Child Welfare League of America.

Dawn, S. (2019, September 20). Seven children are abused daily in Pakistan: Report. Dawn. Retrieved 2020, from https:/ / www.dawn.com/news/1506224

Doane, D. (2018, February 25). Sex abuse claims expose a culture of large NGOs wrapped in self-delusion. The Guardian. Retrieved 2020, from https:/ / www.theguardian.com/society/2018/feb/25/aid-agencies-sex-abusesave-the-children-justin-forsyth

Duiker, W.J., and Spielvogel, J.J. (2016). The essential world history, Volume 1: to 1800 (8 $8^{\text {th }}$ ed., p. 14). Cengage Learning.

Dunne, M.P., Chen, J.Q., and Choo, W.Y. (2008). The Evolving Evidence Base for Child Protection in Chinese Societies. Asia Pacific Journal of Public Health, 20(4), 267-276. doi:10.1177/1010539508325047

Dunne, M.P., Choo, W.Y., Madrid, B., Subrahmanian, R., Rumble, L., Blight, S., and Maternowska, M.C. (2015). Violence Against Children in the Asia Pacific Region. Asia Pacific Journal of Public Health, 27(8_suppl). doi:10.1177/10105 39515602184

Elkin, M. (2020, January 14). Child abuse extent and nature, England and Wales: Year ending March 2019. Retrieved July 04, 2020, from https:/ / www.ons.gov.uk/peoplepopulationandcommunity/crimeandjustice/ articles/childabuseextentandnatureenglandandwales/yearendingmarch2019

Express News Services. (2019). Only Two Cases of Child Sexual Abuse Disposed in Six Months: Supreme Court. Indian Express. Retrieved 2020, from https:/ /indianexpress.com/article/india/only-two-cases-of-child-sexualabuse-disposed-in-six-months-supreme-court-5831157/

Fang, X., Fry, D.A., Ji, K., Finkelhor, D., Chen, J., Lannen, P., and Dunne, M.P. (2015). The burden of child maltreatment in China: A systematic review. Bulletin of the World Health Organization, 93(3). doi:10.2471/blt.14.140970

Feng, J. (2018, January 15). China's First Man on Man Rape Conviction. SupChina. Retrieved 2020, from https://supchina.com/2018/01/15/sexual-assault-casebetween-males/

Finkelhor, D. (2019). Child Sex Abuse Challenges Facing Child Protection and Mental Health Professionals. In CHILDHOOD AND TRAUMA: Separation, abuse, war (pp. 101-115). Place of publication not identified: ROUTLEDGE. 
Fu, H., Feng, T., Qin, J., Wang, T., Wu, X., Cai, Y., . . . Yang, T. (2018). Reported prevalence of childhood maltreatment among Chinese college students: A systematic review and meta-analysis. Plos One, 13(10). doi: 10.1371/journal. pone.0205808

Gaidhane, A.M., Zahiruddin, Q.S., Waghmare, L., Shanbhag, S., Zodpey, S., and Joharapurkar, S. R. (2008). Substance abuse among street children in Mumbai. Vulnerable Children and Youth Studies, 3(1), 42-51. doi:10.1080/17450120 701843166

Gandhara. (2019, March 06). Pakistan Gang Rape Victim Unsure of Justice. Retrieved July 04, 2020, from https://gandhara.rferl.org/a/pakistan-gang-rape-victimunsure-of-justice-/29806747.html

Gannon, K. (2020, April 13). Child sex abuse in Pakistan's religious schools is endemic. $A B C$ News. Retrieved 2020, from https://abcnews.go.com/ International/wireStory/child-sex-abuse-pakistans-religious-schools-endemic70113903

HEAL. (2017, December 19). Preliminary Assessment of Quality and Accessibility of Mental Health Services for Survivors of Child Sex Abuse in Mumbai [PDF]. Mumbai: HEAL Foundation.

Hernandez, J.C. (2020, April 13). Anger Erupts in China After Teen Says Guardian Repeatedly Raped Her. The New York Times. Retrieved 2020, from https:/ / www.nytimes.com/2020/04/13/world/asia/china-metoo.html

Human Rights Commission of Pakistan. (2017, May). State of Human Rights in 2016 [PDF].

Humanium. (2019, April 03). Children of Afghanistan. Retrieved June 04, 2020, from https:/ / www.humanium.org/en/afghanistan/

Hussain, S.A. (1982). Battered Child Syndromes*: What Should a Physician Should Know About It. Journal of Pakistan Medical Association.

India, Ministry of Home Affairs, National Crime Record Bureau. (2015). Crime in India. Retrieved 2020, from https:/ / ncrb.gov.in/crime-india-year-2015.

India, Ministry of Women and Child. (2012). Protection of Children from Sexual Offence Act of 2012. Retrieved 2020, from https://wcd.nic.in/sites/default/files/ POCSO \%20Act \%2C\%202012.pdf

Internet Watch Foundation. (2020). IWF 2019 Annual Report: Zero Tolerance. Retrieved July 04, 2020, from https://www.iwf.org.uk/report/iwf-2019annual-report-zerotolerance?gclid=EAIaIQobChMIyaPxq62x6QIVBobVCh248 w2eEAAYASAAEgJDnvD_BwE

Iravani, M.R. (2011). Child Abuse in India. Asian Social Science, 7(3). doi:10.5539/ ass.v7n3p150

Jabeen. (2013). A History of Contemporary Child Protection in the Global South with a Special Focus on South Asia and Pakistan, J.R.S.P., 50(1), 138-159.

Jan Willem De Lind Van Wijngaarden, and Rani, B. (2011). Male adolescent concubinage in Peshawar, Northwestern Pakistan. Culture, Health $\mathcal{E}$ Sexuality, 13(9), 1061-1072. doi:10.1080/13691058.2011.599863

Jan Willem De Lind Van Wijngaarden, and Schunter, B.T. (2014). 'Part of the job': Male-to-male sexual experiences and abuse of young men working as 'truck cleaners' along the highways of Pakistan. Culture, Health $\mathcal{E}$ Sexuality, 16(5), 562574. doi:10.1080/13691058.2014.891051 
Jonsson, L.S., Fredlund, C., Priebe, G., Wadsby, M., and Svedin, C.G. (2019). Online sexual abuse of adolescents by a perpetrator met online: A cross-sectional study. Child and Adolescent Psychiatry and Mental Health, 13(1). doi:10.1186/s13034-019-0292-1

Khan, A. (2015, July 2). WAR report 2014: Four women raped every day in Pakistan. The Express Tribune. Retrieved 2020, from https://tribune.com.pk/story/ 913772/miserable-figures-rape-a-bigger-problem-than-meets-the-eye/

Khan, M.I. (2020, March 12). Pakistan Zainab Murder New Law Aims to Catch Child Abusers. BBC News. Retrieved 2020, from https://www.bbc.com/news/worldasia-51852381

Khan, P. (2017, July 1). Child maids' rape cases on rise in Pakistan. News Lens Pakistan. Retrieved 2020, from http://www.newslens.pk/child-maids-rapecases-rise-pakistan/

Khan, S. (2020, February 2). Making children safer. The News on Sunday. Retrieved 2020, from https://www.thenews.com.pk/tns/detail/606913-making-children -safer

Khan, T.A. (2019, April 10). Child abuse in Pakistan. The Nation. Retrieved 2020, from https://nation.com.pk/10-Apr-2019/child-abuse-and-pakistan

Lin, D., Li, X., Fan, X., and Fang, X. (2011). Child sexual abuse and its relationship with health risk behaviors among rural children and adolescents in Hunan, China. Child Abuse \& Neglect, 35(9), 680-687. doi: 10.1016/j.chiabu.2011.05.006

Markel, H., M.D. (2009, December 4). Case Shined First Light on Abuse of Children. The New York Times.

Mason, M.A. (1994). From father's property to children's rights: The history of child custody in the United States. New York, NY: Columbia University Press.

Masood, S. (2019, October 3). Rapes and Killings of Children Haunt a Corner of Pakistan. The New York Times. Retrieved 2020, from https:/ / www.nytimes.com /2019/10/03/world/asia/pakistan-child-rapes-killings-kasur.html

McCoid, A.H. (1965). The Battered Child and Other Assaults upon the Family: Part One" (1965). Minnesota Law Review.

McCoy, A. (2014, August 04). UNICEF: A statistical snapshot on child abuse in East Asia and the Pacific. Retrieved June 26, 2020, from http://childsafetourism.org/unicef-statistical-snapshot-child-abuse-east-asiapacific/

Mid West man charged over vile child sex abuse videos. (2020, April 21). The West Australian. Retrieved 2020, from https://thewest.com.au/news/crime/midwest-man-charged-over-vile-child-sex-abuse-videos-ng-b881526614z

Mills, J. (2015, June 15). The last Women in China with Bound Feet: They Thought It Would Give Them A Better Life. The Guardian. Retrieved 2020, from https:/ / www.theguardian.com/artanddesign/2015/jun/15/the-last-womenin-china-with-bound-feet

Mimiaga, M.J., Closson, E.F., Thomas, B., Mayer, K.H., Betancourt, T., Menon, S., and Safren, S.A. (2014). Garnering an In-depth Understanding of Men Who Have Sex with Men in Chennai, India: A Qualitative Analysis of Sexual Minority Status and Psychological Distress. Archives of Sexual Behavior, 44(7), 2077-2086. doi:10.1007/s10508-014-0369-0 
Mubashir, M.A. (2019, December 28). Minor boy subjected to rape by 100 times. Daily Times. Retrieved 2020, from https://dailytimes.com.pk/528288/minorboy-subjected-to-sexual-assault-by-100-times /

Mubashir, M.A. (2020, January 27). A family in Mansehra accused JUI-F leader for threatening in a child abuse case. Daily Times. Retrieved 2020, from https:/ / dailytimes.com.pk/547326/a-family-in-mansehra-accused-jui-f-leaderfor-threatening-in-a-child-abuse-case/

Muzari, S. (2019). BILL to Make Provisions for Raising Alert, Response and Recovery of Missing and Abducted Children (Pakistan, National Assembly, Federal Minister for Human Rights). Retrieved 2020, from http://www.na.gov.pk/uploads/ documents/1556103569_454.pdf

Naseer, T. (2018, August 10). 11-year-old boy raped allegedly by three men in Taxila. Dawn. Retrieved 2020, from https:/ / www.dawn.com/news/1426169

News 18. (2019). Four Men Sodomise 13-Year-old Boy in Uttar Paradesh Village All Accused Absconding. News 18. Retrieved 2020, from https:/ / www.news18.com/news/india/four-men-sodomise-13-year-old-boyin-uttar-pradesh-village-all-accused-absconding-2189079.html

O'Leary, P., Cameron, C. M., Lakhani, A., Osborne, J. M., Souza, L. D., Hope, K., . . . Majidi, S. (2018). Violence against children in Afghanistan: Concerns and opportunities for positive change. Child Abuse \& Neglect, 76, 95-105. doi: 10.1016/j.chiabu.2017.10.010

Omer, S. (2020, February 6). Massive increase in rapes, child sexual abuse in Punjab. Pakistan Today. Retrieved 2020, from https://www.pakistantoday.com.pk/ 2020/02/05/ massive-increase-in-rapes-child-sexual-abuse-in-punjab/

Pakistan, Ministry of Social Welfare and Special Education. (2006). National Action Plan for Children. Retrieved 2020, from https://hivhealthclearinghouse. unesco.org/sites/default/files/resources/iiep_npa_pakistan.pdf

Public Health Foundation of Georgia, Child Abuse - A Historical Perspective. (n.d.). Retrieved June 03, 2020, from http://phf.org.ge/en/resources/child-abuse-ahistorical-perspective-/

Putnam, F.W. (2003). Ten-year research update review: child sexual abuse. Journal of the American Academy of Child Adolescent Psychiatry, 42(3): 269-278

Qiao, D.P., and Chan, Y.C. (2005). Child abuse in China: A yet-to-be-acknowledged 'social problem' in the Chinese Mainland. Child Family Social Work, 10(1), 21-27. doi:10.1111/j.1365-2206.2005.00347.x

Sahay, S. (2008). Socio-Cultural Factors and Young Sexual Offenders: A Case Study of Western Madhya Pradesh (India). International Journal of Adolescence and Youth, 14(2), 113-134. doi:10.1080/02673843.2008.9747998

Sandhu, Akhtar. (2018). Rape of A Seven-Year-Old Girl in Kasur, Pakistan: Maladministration in The Punjab. Research Gate.10.13140/RG.2.2.26076.28807.

Schiavenza, M. (2013). The Peculiar History of Foot Binding in China. The Atlantic. Retrieved 2020, from https://www.theatlantic.com/china/archive/2013/09/ the-peculiar-history-of-foot-binding-in-china/279718/

Sengupta, N. (2020, January 12). 109 Children Sexually Abused Every Day in India in 2018: NCRB. India Today. Retrieved 2020, from https://www.indiatoday.in/ india/story/109-children-sexually-abused-every-day-india-2018-1636160-202001-12 
Smith, E.L., and Stroop, J. (2019, December 11). Sexual Victimization Reported by Youth in Juvenile Facilities, 2018 (United States of America, Bureau of Justice Statistics, Office of Justice Programs). Retrieved 2020, from Office of Justice Programs

Song, Y., Ji, C., and Agardh, A. (2014). Sexual coercion and health-risk behaviors among urban Chinese high school students. Global Health Action, 7(1), 24418. doi:10.3402/gha.v7.24418

Tang, C.S. (2002). Childhood experience of sexual abuse among Hong Kong Chinese college students. Child Abuse \& Neglect, 26(1), 23-37. doi:10.1016/s01452134(01)00306-4

Teenager raped seven-year-old boy in graveyard. (2019, January 16). BBC News. Retrieved 2020, from https://www.bbc.com/news/uk-scotland-glasgow-west46895220

Thirty-three men arrested over Halifax child sex abuse. (2019, February 4). BBC News. Retrieved 2020, from https://www.bbc.com/news/uk-england-leeds47120659

Thompson, R., Lewis, T., Neilson, E. C., English, D. J., Litrownik, A. J., Margolis, B., . . . Dubowitz, H. (2016). Child Maltreatment and Risky Sexual Behavior. Child Maltreatment, 22(1), 69-78. doi:10.1177/1077559516674595

Times Now News. (2019). Six Men Sodomise Minor Boy in Kolkata's Khidderpore Area. Times Now News. Retrieved 2020, from https://www.timesnownews. com/mirror-now/crime/article/kolkata-police-on-lookout-for-five-otherswho-sodomised-minor-boy-in-moving-car/510211

Tomori, C., Mcfall, A.M., Srikrishnan, A.K., Mehta, S.H., Nimmagadda, N., Anand, S., . . Celentano, D. D. (2016). The prevalence and impact of childhood sexual abuse on HIV-risk behaviors among men who have sex with men (MSM) in India. BMC Public Health, 16(1). doi:10.1186/s12889-016-3446-6

Turpin trial: Couple jailed for life for 'inhuman' child abuse. (2019, April 19). BBC News. Retrieved 2020, from https://www.bbc.com/news/world-us-canada47991829

UNICEF EAPRO. Violence Against Children in East Asia And Pacific, Strengthening Child Protection Systems Series, No. 4 [PDF]. (2014). Bangkok: UNICEF.

UNICEF. (2017). UNICEF Annual Report: China [PDF]. UNICEF.

UNICEF. UNICEF's role in promoting and supporting the Convention on the Rights of the Child. (n.d.). Retrieved June 13, 2020, from https://www.unicef.org/ child-rights-convention/unicef-role

UNICEF. What is the Convention on the Rights of the Child? (n.d.). Retrieved June 03, 2020, from https://www.unicef.org/child-rights-convention/what-is-theconvention

United States of America, United States Department of State, Bureau of Democracy, Human Rights and Labor. (2019). Pakistan 2019 Human Rights Report. Retrieved 2020, from https://pk.usembassy.gov/wp-content/uploads/sites/76/ PAKISTAN-2019-HUMAN-RIGHTS-REPORT.pd

United States of America, West Virginia Judiciary, Supreme Court of Appeals of West Virginia. (n.d.). Rules of Procedure for Child Abuse and Neglect Proceedings. Retrieved 2020, from http://www.courtswv.gov/legal-community/courtrules/child-abuse/abuse-1-25.html\#rule1 
United States of America. Administration for Children and Families. U.S. Department of Health and Human Services. (2019). Child abuse, neglect data released. Retrieved July 04, 2020, from https://www.acf.hhs.gov/media/ press/2019/child-abuse-neglect-data-released

Watkins, S.A. (1990). The Mary Ellen Myth: Correcting Child Welfare History. Social Work, 35(6), 500-503. doi:10.1093/sw/35.6.500

Weisberg, K. (1984). The "Discovery" of Sexual Abuse: Experts' Role in Legal Policy Formulation. U.C. Davis Law Review, 18(1), 1-2, n.1.

Widom, C.S., Czaja, S.J., Bentley, T., and Johnson, M.S. (2012). A prospective investigation of physical health outcomes in abused and neglected children: New findings from a 30-year follow up. American Journal of Public Health, 102, 1135-1144.

Wolfe, V.V. (2007). Child sexual abuse. In E.J. Mash and R.A. Barkley, eds., Assessment of Childhood Disorders (4th ed.) (pp. 685-748), New York: Guilford Press

World Health Organization. (2020, June 8). Child maltreatment. Retrieved July 04, 2020, from https://www.who.int/en/news-room/fact-sheets/detail/childmaltreatment

Wu, N. (2014, September 25). Chinese Man Accused of Raping Another Man Walks Free Due to Loophole in The Criminal Law. South China Morning Post. Retrieved 2020, from https://www.scmp.com/news/china/article/1600213/ chinese-suspect-who-raped-another-man-walks-free-due-loophole-criminal

Yan, A. (2019, May 31). Millions of children in China 'victims of sexual assault'. South China Morning Post. Retrieved 2020, from https://www.scmp.com/ news/china/society/article/3012658/millions-children-china-victims-sexualassault

Yong, X. (2015). Child Protection. Retrieved June 12, 2020, from https:/ / www.unicef.cn/en/what-we-do/child-protection

Yuan, T. (2019, July 5). China's child sexual abuse in numbers. CGTN. Retrieved 2020, from https://news.cgtn.com/news/2019-07-05/China-s-child-sexualabuse-in-numbers-I5pkWzJrjO/index.html

Zhang, J., and Chen, T. (2019, September 20). China's First Regulation on the Protection of Children's Personal Information. Retrieved May 20, 2020, from https://www.lexology.com/library/detail.aspx?g=8a1da201-15a8-4e15-8c3364fda8fbf621

Zheng, Z. (2017, May 26). China's Child Rape Laws Fall Hopelessly Short. Retrieved May 30, 2020, from http://www.sixthtone.com/news/1030/how-china \% E2\%80\%99s-child-rape-laws-are-full-contradictions

Zulgernain, M. (2019). Imran Khan Removes Three Top Punjab Police Officers After Sexual Assault Murder of Three Minor Boys. Outlook India. Retrieved 2020, from at https://www.outlookindia.com/newsscroll/imran-removes-toppunjab-police-officers-after-sexual-assault-murder-of-three-minorboys/1623466. 